\section{A descoberta do mundo depois da Copa de 1994}

\section{Tatiana Pequeno}

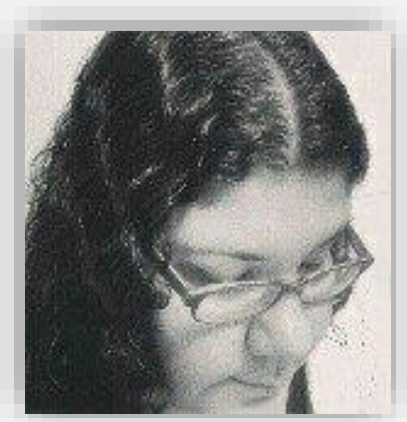

É autora dos livros de poesia Aceno (2014) e Réplica das urtigas (2009). Professora de Literaturas Portuguesa e Africanas da UFF Niterói/RJ. Doutora em Vernáculas pela UFRJ, com tese sobre Maria Gabriela Llansol.

Tijucana e "lusitana" que é, de longe (e de perto), ela torce pelo Vasco, clube que homenageia o descobridor do caminho marítimo para as Índias, Vasco da Gama (1469-1524), nascido em Sines, mesma cidade de Al Berto, poeta marcante na trajetória acadêmica e literária da autora.

Ao escrever poesia, Tatiana Pequeno reflete muito a respeito da própria escrita e da vida contemporânea, "a poesia é apenas um modo particular de enfrentar o mundo, de através de um universo microscópico estar à deriva com tantos outros", diz no derradeiro texto de Aceno.

Aqui, com o humor e a sensibilidade de quem é afetada pela cidade, por meio da inscrição pichada perto da rodoviária do Rio - "vitória consagradora do Jorginho" -, a autora mostra o futebol a partir de seu modo singular de nomear o mundo - "nós, as meninas, em 1994". deve ter uns vinte anos que passo naquele viaduto e leio há tempos perto da rodoviária na Leopoldina a mesma frase que diz comovida

\section{vitória consagradora do Jorginho}

creio ter a ver com a conquista brasileira na copa de 1994 e de como o jogador chamado Jorginho, grande lateral direito, superou o descrédito a desconfiança e a insegurança que vinham de uma seleção burocrática no maior torneio eliminatório das Américas para os meus olhos bastante adolescentes de uma década de longo tempo sem gols.

não sei bem porque a frase permanece lá depois de tanto sol tantas obras tanto pó ainda

só consigo pensar no gesto de alguém um homem

comprando pincel e tinta branca e indo escrever no concreto uma declaração pública de identificação íntima com o jogo e a superação daquele Jorginho que, ao mesmo tempo, compunha parte das figurinhas que tive no álbum da campanha futebolística de 1994 embora de minha parte houvesse mesmo um 
encanto pelo Ricardo Rocha, zagueiro espiritual de verve vascaína e nordestina que conheci por ter irmã de maiô competitivo preto e branco, ginasta daquele clube onde tudo o que consegui foi um autógrafo do Capitão que colei em meu caderno verde e amarelo de poemas.

nós, as meninas, em 1994, queríamos falar dos jogos, do nervosismo do Dunga mas a mim, na oitava série, diziam era que jamais me casaria com Leonardo, aquele que foi expulso no jogo contra os americanos por ter acertado uma pontiaguda cotovelada.

lembro-me da vitória consagradora do Jorginho e sei que após os jogos esta frase fazia sempre muito sentido no tempo que se seguiu e penso que tenha a ver com a adversidade que soube anos depois a caminho da faculdade na ilha distante do Fundão onde sempre terminar alguma coisa tinha a ver com vencer e ganhar realmente uma outra sensibilidade com isso.

fato é que o tempo já se faz há muito e como de fato não me casei com o Leonardo pois para mim as mulheres talvez tenham sido mais sensíveis e conversadoras que conservadores (por que diabos os meninos me interditavam fosse o Branco, o Jorginho ou o Leonardo?) e assim, a verdade é que jamais fui muito de jogos - além de nunca ter ido adiante com o vôlei no Bonsucesso Futebol Clube - entendi que mais que conhecer o Jorginho, queria mesmo era saber do autor do piche, conhecer o motivo da sua inscrição, reconhecê-lo como sujeito não de uma ajuda mas de uma suspeita que por mais de vinte anos perdurou pela consagração de um personagem que ao vencer nos salva a ponto de agradecermos por meio de uma escrita algo como obrigado, Jorginho pelo seu jogo, e dito isso fica claro que nele me identifico porque sei que preciso vencer este concreto porque sei que preciso passar esta linha vermelha porque sei que preciso aprender a jogar a bola porque um dia pensei que um livro fosse para escrever sobre

essa vitória consagradora mas aqui

nesta época sem caderno verde-amarelo sem editora sem o dinheiro do Jorginho sem bolas não foi

não fui

não consegui. 